\title{
Neuropsychiatrische comorbidi- teit bij mensen met epilepsie en verstandelijke beperking
}

Op 9 januari 2019 promoveerde Jans van Ool aan de Universiteit Maastricht op haar proefschrift 'Diagnostic and neuropsychiatric considerations in epilepsy and intellectual disability' ${ }^{\mathrm{I}}$. In het proefschrift staat beschreven welke kenmerken binnen de epilepsie en verstandelijke beperking samenhangen met verschillende soorten neuropsychiatrische problematiek en worden de diagnostische implicaties hiervan besproken.

\section{Epilepsie en verstandelijke beperking}

Epilepsie komt relatief vaak voor bij mensen met een verstandelijke beperking (VB), met een gepoolde prevalentie van 22.2\% (Robertson et al., 2015). Bij mensen met een VB is de epilepsie vaker ernstig, chronisch en moeilijk te behandelen dan bij mensen zonder een VB, hetgeen een grote invloed kan hebben op de kwaliteit van leven (Kerr et al., 2014). Uit eerdere studies is bekend dat zowel epilepsie als een VB afzonderlijk samenhangen met het vaker optreden van neuropsychiatrische comorbiditeit, maar over de combinatie epilepsie én VB in relatie tot neuropsychiatrie is nog betrekkelijk weinig bekend.

\section{Aspecten binnen de diagnostiek}

Het eerste deel van het proefschrift is gericht op methodologische aspecten van diagnostiek naar de VB, stemming en angst. Met betrekking tot de VB zijn de meest recente classificatiecriteria van de DSM-5 aangehouden. Deze is gericht op het vaststellen van de mate van beperking voor drie domeinen van adaptief functioneren: het conceptuele, sociale en praktische domein. In het onderzoek zijn methoden beschreven om op gestandaardiseerde wijze ieder domein afzonderlijk en een discrepantie tussen de domeinen (het ene domein is beduidend meer beperkt dan een ander domein) vast te stellen. Dit is toegepast bij I89 volwassenen met epilepsie en VB. Een discrepantie tussen de domeinen kwam bij bijna een derde van de patiënten voor, met name bij mensen met een matige VB (53\%). Deze discrepantie bleek samen te hangen met een focale vorm van epilepsie en met een hoger aantal verschillende aanvalstypen. In de dagelijkse praktijk is het van belang om bij een VB rekening te houden met een discrepantie tussen de verschillende domeinen door de behandeling en/of begeleiding op de sterke en zwakke kanten van een persoon af te stemmen.

Uitgebreide diagnostiek is belangrijk voor een passende behandeling, maar kan tijdrovend en belastend zijn. Vanuit de klinische praktijk is er daarom interesse in betrouwbare (verkorte) meetinstrumenten. In het proefschrift zijn verkorte versies van onder andere een intelligentietest voor volwassenen, de WAIS-IV, onderzocht bij 324 patiënten met neurologische aandoeningen, waaronder epilepsie. Bepaalde verkorte versies bleken geschikt, ook bij mensen met een zeer lage intelligentie, en zijn daarom bruikbaar om een globale schatting te geven van de intelligentie en voor het screenen van eventuele intellectuele achteruitgang. Verder is de angst- en stemmingsvragenlijst voor mensen met een VB (ADESS) multicentrisch onderzocht bij I98 volwassenen onder de 50 jaar. De betrouwbaarheid bij mensen van 50 jaar en ouder is reeds in een eerder onderzoek vastgesteld. Het bleek dat de ADESS voldoende valide en betrouwbaar was om regelmatig te screenen op angst- en stemmingsklachten.

\section{Relatie met neuropsychiatrie}

Het tweede deel van het proefschrift behandelt de samenhang tussen neuropsychiatrische problematiek (met name angst, stemmings- en gedragsproblematiek) en specifieke kenmerken van epilepsie en VB. Uit systematisch literatuuronderzoek bleek dat er slechts vijftien studies van voldoende kwaliteit over dit onderwerp zijn gepubliceerd, met inconsistente resultaten. Vervolgens is prospectief onderzoek opgezet, waarbij epilepsie- en VB-kenmerken en neuropsychiatrische problematiek in kaart zijn gebracht 


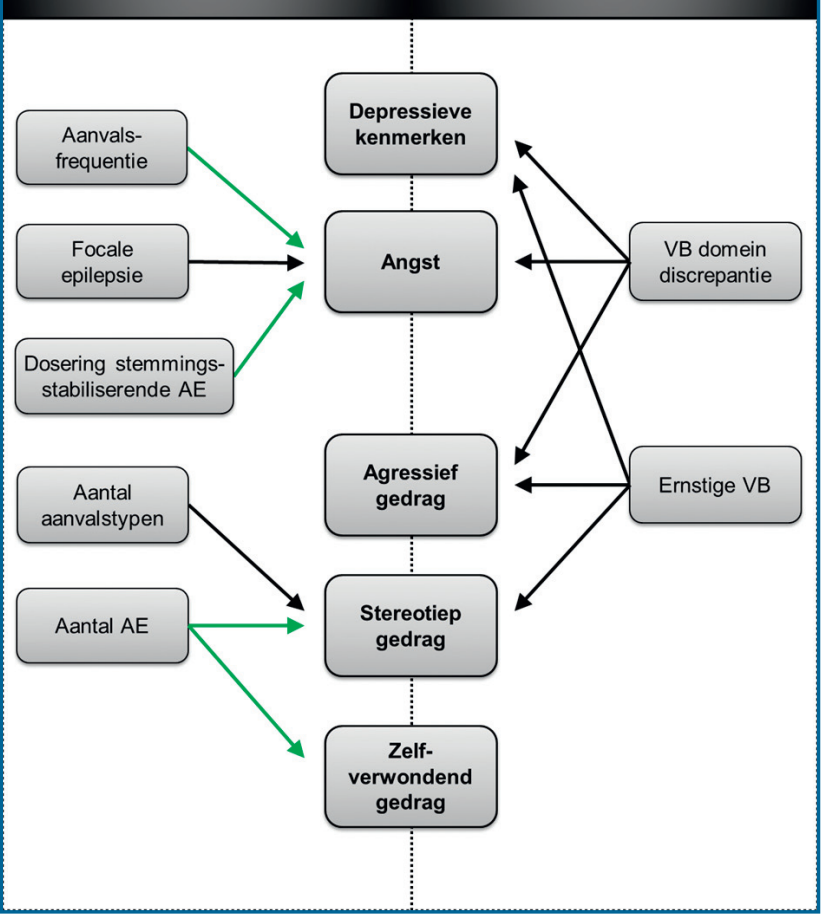

Figuur 1 Overzicht van significante relaties op basis van regressieanalyses, gecorrigeerd voor de overige epilepsie-, VB- en demografische kenmerken. Zwarte pijlen verwijzen naar positieve verbanden en groene pijlen naar negatieve (omgekeerde) verbanden.

\section{$\mathrm{AE}=$ anti-epileptica}

bij I89 volwassenen.

Verhoogde angst- en depressieve klachten bleken voor te komen bij respectievelijk 22\% en I3\% van de deelnemers en frequent probleemgedrag bij $29 \%$. De resultaten zijn samengevat in figuur I en laten zien dat VB-kenmerken, met name het hebben van een VB domein-discrepantie, sterker samenhangen met depressieve kenmerken, angst en gedragsproblemen dan epilepsiekenmerken. Daarnaast blijken er enkele epilepsiekenmerken te zijn, zoals een hogere aanvalsfrequentie en groter gebruik van (stemmingsstabiliserende) anti-epileptica, die negatief gerelateerd zijn aan neuropsychiatrische klachten (dus samenhangen met minder angst en gedragsproblemen). Ondanks dat de representativiteit van de steekproef beperkt is tot volwassenen met veelal ernstige epilepsie die behandeld werden in een tertiair epilepsiecentrum, toont het onderzoek aan dat neuropsychiatrische comorbiditeit een belangrijk aandachtspunt is voor deze doelgroep. De invloed van specifieke epilepsiekenmerken op het gedrag lijkt anders te zijn dan in de praktijk soms verondersteld wordt.

\section{Tot slot}

De bevindingen kunnen professionals en andere betrokkenen helpen bij het kiezen van diagnostische methoden, het screenen op neuropsychiatrische comorbiditeit en het optimaliseren van het behandelplan. Daarmee kan de kwaliteit van zorg worden verbeterd.

De samenhang tussen epilepsie, VB en neuropsychiatrie is en blijft complex en er dienen vele individuele factoren in acht te worden genomen. Een multidisciplinaire aanpak wordt daarom sterk aanbevolen.

\section{Referenties}

Robertson J, Hatton C, Emerson E, Baines S (2015)

Prevalence of epilepsy among people with intellectual disabilities: A systematic review. Seizure 2015;29:46-62. Kerr M, Linehan C, Thompson R, Mula M, Gil-Nagal A, Zuberi SM, Glynn M (2014) A White Paper on the medical and social needs of people with epilepsy and intellectual disability: The Task Force on Intellectual Disabilities and Epilepsy of the International League Against Epilepsy. Epilepsia 2014;55(12):1902-6.

\title{
Hebt u de website van het Epilepsiefonds al bekeken?
}

\author{
www.epilepsie.nl
}

